The International Journal of Knowledge, Culture and Change Management

Volume 3

Article: MC03-0071-2003

Edited by Mary Kalantzis and Bill Cope

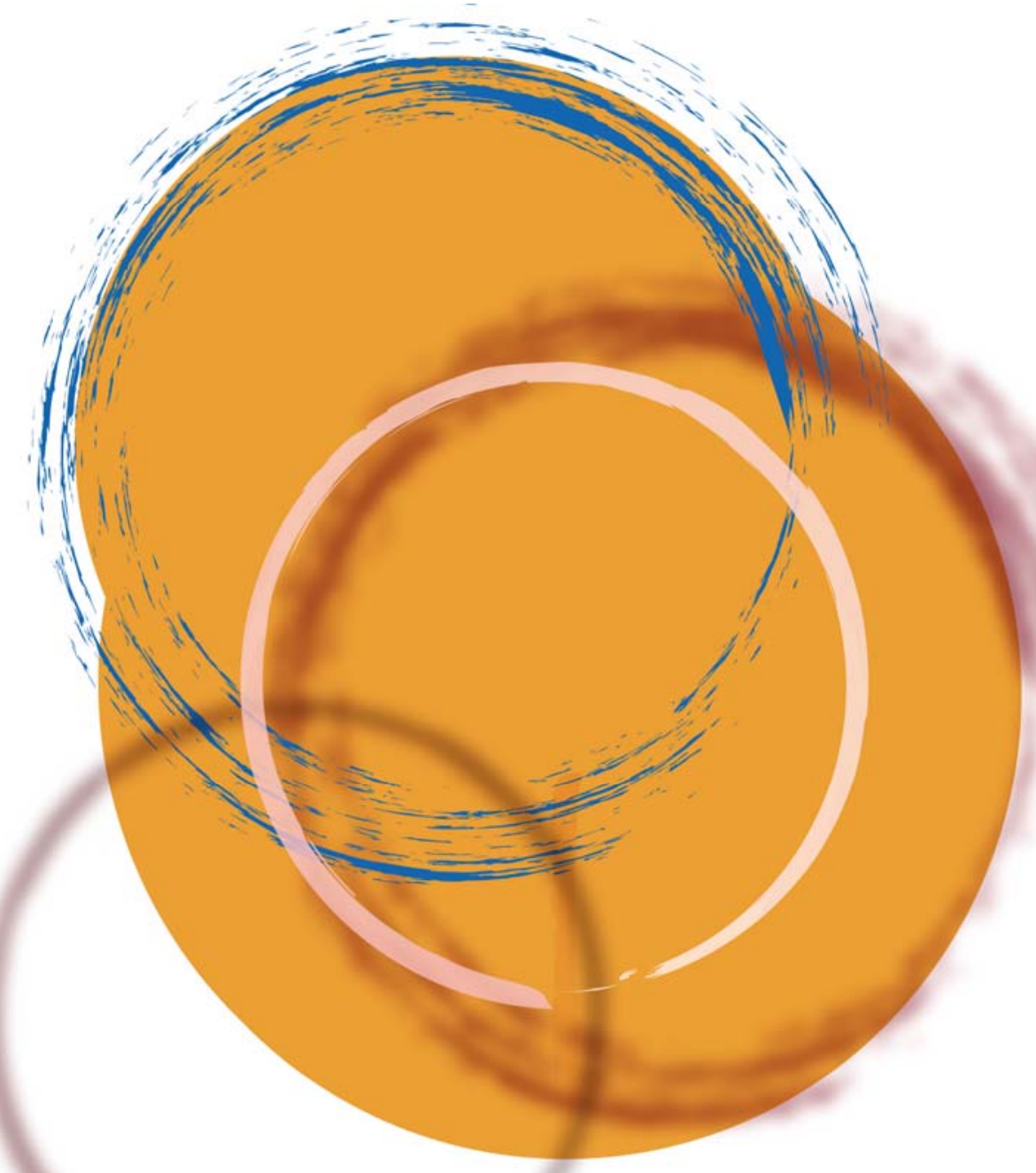

Boundaries and Knowledge Sharing

A Case Study of Two Multinationals

David Meacheam and Raelee Hobson 
This journal and individual papers published at http://ManagementConference.Publisher-Site.com/ a series imprint of theUniversityPress.com

First published in Australia in 2003-2005 by Common Ground Publishing Pty Ltd at http://ManagementConference.Publisher-Site.com/

Selection and editorial matter copyright (C Mary Kalantzis and Bill Cope 2003-2005 Individual chapters copyright (C) individual contributors 2003-2005

All rights reserved. Apart from fair dealing for the purposes of study, research, criticism or review as permitted under the Copyright Act, no part of this book may be reproduced by any process without written permission from the publisher.

ISSN: 1447-9524 (Print)

ISSN: 1447-9575 (Online)

Cover design by Common Ground

Papers presented at the Third International Conference on Knowledge, Culture and Change in Organisations, Bayview Beach Resort, Penang, Malaysia, 11-14 August 2003. 


\title{
Boundaries and Knowledge Sharing
}

\author{
A Case Study of Two Multinationals
}

David Meacheam and Raelee Hobson

\begin{abstract}
This case study examines how a major multinational food manufacturer, Master Foods, and a major office technology supplier, Fuji Xerox, cope with the problems of developing, sharing and maximising the use of knowledge in their organisations.

The paper sets out a typology of analysing organisational knowledge management, developed by the authors, and applies that model to the two companies under study. It draws extensively upon material gathered in interviews with three middle managers from Master Foods Australia and four middle managers from Fuji Xerox Australia, providing a rich picture of two very different approaches to knowledge management in a multinational setting.
\end{abstract}

\section{Introduction}

In an earlier work (Meacheam and Hobson 2001), the authors analysed the efforts of Master Foods Australia and Fuji Xerox Australia to better integrate with their overseas operations, and in particular their efforts to maximise the use of their internal stores of knowledge. The authors contrasted Master Foods Australia, the 'people' organisation, with Fuji Xerox Australia, the 'paper' or document organisation.

In the space of just one year, both organisations have moved dramatically in terms of how they manage knowledge. In the instance of Master Foods, there has occurred a global restructure that supports a degree of regional and national autonomy. That restructure has had repercussions in terms of how the organisation manages knowledge. Master Foods has also undertaken both a concerted attempt at implementing a global information management system (SAP) and a knowledge management initiative. In the instance of Fuji Xerox Australia, structural changes have occurred, with an Oracle regional hub being implemented from Singapore (the regional HQ), and Singapore assuming regional responsibility for inventory control. For Fuji Xerox Australia, the organisational boundaries have changed. A reporting relationship previously with an office situated 7 hours away is now with an office that is active 'over the back fence', with Fuji Xerox Singapore operating in the same geographic region as Fuji Xerox Australia.

This paper sets out a typology of analysing organisational knowledge management, developed by the authors, and applies that model to the companies under study. It draws upon material gathered in interviews with seven strategically situated middle managers across the two organisations, to provide a rich picture of two very different approaches to knowledge management in a multinational setting. The authors' view of these positions as being strategic is based on the depth of the experiences of those interviewed and the breadth of their responsibilities. 


\section{Study Methodology}

\section{Participants}

Relying upon the method of Yin (Yin 1994) and Sarantakos (Sarantakos 1993), the researchers focussed upon interviewing elite, expert sources within both Master Foods and Fuji Xerox. The people interviewed in each organisation were those identified by the contact person as both representative of the general population and expert in terms of their insights.

The participants in this study were as follows:

Master Foods: The Strategic Communication Manager for Australia and New Zealand, the Information Technology Manager and the Information Delivery Analyst.

Fuji Xerox Australia: The Finance Director, National Product Manager, Human Resource Operations Manager, Business Systems Manager, the Commercial Manager.

Interviews averaged about one hour. The responses to the interview questions were analysed within a matrix developed by the authors. Interview questions were structured around a typology of knowledge management developed by Chun Wei Choo (Choo 1997). Choo sees the knowledge management process as comprising of sense-making, knowledge creation and decision-making. The Choo typology was coupled with Albert Bressand and Catherine Distlers' socio-technical system of analysis, which sees organisational knowledge as being influenced by the organization's infrastructure, infostructure and infoculture. In combining these two models the authors captured the notions of knowledge as having the characteristics of both a process (Spender, 1996) and an artefact within organisations (Newell, Robertson, Scarbrough and Swan, 2002). The notions of infrastructure, infostructure and infoculture are expansive enough to cover knowledge management interactions both within the organisations and beyond, to the customers, suppliers and others who shape their knowledge management practice.

The Bressand and Distler view of organisations socio technical systems consists of the following (Bressand and Distler, 1995):

The infrastructure consists of the hardware/software which enables the physical/communicational contact between network members. In the instance of this analysis, this definition has been extended beyond IT and communicational elements to include consideration of the physical work environments.

The Infostructure is the formal rules which govern the exchange between the actors on the network, providing a set of cognitive resources (metaphors, common language) whereby people make sense of events on the network. In the instance of this analysis infostructure includes the formal reporting elements between Fuji Xerox Australia and Fuji Xerox Asia Pacific, and Master Foods Australia and the worldwide Mars group of which it is part.

The Infoculture is the stock of background knowledge which actors take for granted and which is embedded in the social relations surrounding work group processes. This cultural knowledge defines constraints on knowledge and information sharing. In the instance of this analysis, this includes examination of the exchanges 
between disciplines and national cultures and the preferences for the media for knowledge exchange.

The responses to the questions posed were analysed and applied to the following matrices.

Analysis of Master Foods Australia

\begin{tabular}{|c|c|c|c|}
\hline & Infrastructure & Infostructure & Infoculture \\
\hline Sense making & $\begin{array}{l}\text { - Data-mining, CRM } \\
\text { software, Some } \\
\text { reliance on externally } \\
\text { focussed competitive } \\
\text { intelligence } \\
\text { (e.g.Gartner) } \\
\text { - IT \& communication } \\
\text { system enabled } \\
\text { knowledge sharing. } \\
\text { - Open-plan workplace. } \\
\text { Shift to global, shared } \\
\text { use of SAP. }\end{array}$ & 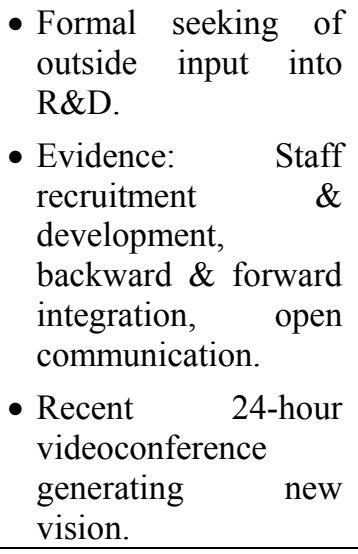 & $\begin{array}{l}\text { - Conversation } \\
\text { assistance via } \\
\text { open office. } \\
\text { - High reliance on } \\
\text { verbal exchanges. }\end{array}$ \\
\hline Knowledge creation & $\begin{array}{l}\text { - Reliance on an } \\
\text { electronic network, } \\
\text { use of groupware. } \\
\text { - Open-plan workplace. } \\
\text { - Shift to global, shared } \\
\text { use of SAP. }\end{array}$ & $\begin{array}{l}\text { - Reliance on cross- } \\
\text { functional teams. } \\
\text { - Strong shared } \\
\text { language. } \\
\text { - Development of } \\
\text { 'Making a } \\
\text { difference' award }\end{array}$ & $\begin{array}{l}\text { - Organisation is } \\
\text { temperamentally } \\
\text { relatively } \\
\text { homogenous } \\
\text { (effect of } \\
\text { recruitment to } \\
\text { cultural 'fit'). } \\
\text { Current efforts to } \\
\text { lessen } \\
\text { homogeneity. }\end{array}$ \\
\hline Decision-making & $\begin{array}{l}\text { - Decision-support } \\
\text { systems, Groupware. } \\
\text { - Shift to global, shared } \\
\text { use of SAP. } \\
\text { - Open-plan workplace }\end{array}$ & $\begin{array}{l}\text { - Continually emerging } \\
\text { autonomy of } \\
\text { Australian \& Asia } \\
\text { Pacific operations. } \\
\text { - Delegated decision- } \\
\text { making. }\end{array}$ & $\begin{array}{l}\text { - Emerging risk- } \\
\text { accepting culture, } \\
\text { endorsed by senior } \\
\text { management }\end{array}$ \\
\hline
\end{tabular}


Analysis of Fuji Xerox Australia

\begin{tabular}{|c|c|c|c|}
\hline & Infrastructure & Infostructure & Infoculture \\
\hline Sense making & $\begin{array}{l}\text { - Geographically } \\
\text { dispersed operation } \\
\text { within Australia. } \\
\text { Managers generally } \\
\text { work solo in own } \\
\text { offices. } \\
\text { - Highly Sophisticated } \\
\text { IT Infrastucture }\end{array}$ & $\begin{array}{l}\text { - Funnel effect via } \\
\text { control from Japan } \\
\text { exerted via } \\
\text { Singapore. } \\
\text { (Inventory } \\
\text { Functional area) } \\
\text { - In some business } \\
\text { areas there is a } \\
\text { tribal mentality } \\
\text { can result in us vs } \\
\text { them }\end{array}$ & $\begin{array}{l}\text { - Evidence of long- } \\
\text { term employment } \\
\text { - Changing from } \\
\text { Sales to IT } \\
\text { Services } \\
\text { Organisation. } \\
\text { - Strong preference } \\
\text { for } \\
\text { communication } \\
\text { via documents }\end{array}$ \\
\hline Knowledge creation & $\begin{array}{l}\text { - Membership of } \\
\text { industry association. } \\
\text { - Use of Docushare } \\
\text { Software for Sharing } \\
\text { of Information. } \\
\text { - Use customers and } \\
\text { suppliers in } \\
\text { knowledge creation }\end{array}$ & $\begin{array}{l}\text { - Godfather system } \\
\text { for branch offices } \\
\text { - Regionally } \\
\text { customised } \\
\text { processes } \\
\text { - Cross functional } \\
\text { Project teams }\end{array}$ & $\begin{array}{l}\text { - Silo-effect, } \\
\text { however, } \\
\text { supported by } \\
\text { comprehensive } \\
\text { Functional } \\
\text { Communication } \\
\text { Process. }\end{array}$ \\
\hline Decision-making & $\begin{array}{l}\text { - Flat hierarchy, four } \\
\text { levels }\end{array}$ & $\begin{array}{l}\text { - Decision-making } \\
\text { powers is } \\
\text { sometimes } \\
\text { bounded by need } \\
\text { for -'upstream' } \\
\text { input. }\end{array}$ & $\begin{array}{l}\text { - Consensus, but } \\
\text { often rule driven } \\
\text { approach to } \\
\text { decision-making }\end{array}$ \\
\hline
\end{tabular}

After entering data to the matrices, the authors compared the results for each organisation, and arrived at a summary regarding knowledge management within each organisation, and the impacts of structure and culture upon knowledge management practice.

\section{Research Strategies}

\section{Data Collection}

An open-ended interview was conducted by one or both of the researchers with each of the participants.

Initial data collection took place in interviews over a four-week period in September 2002. This was followed up with interviews in June and July, 2003. In most instances, respondents were interviewed singularly, to allow them to feel unconstrained by their peers. One interview was conducted by phone.

\section{How the Data was Analysed}

Both the responses from those interviewed, plus the researchers' prior knowledge of both organisations, enabled analysis of factors within the cells of the matrix, as shown in Table I. The questions were framed in terms of Choo's (Choo 1997) division of knowledge management into the broad concerns of sense-making, knowledge creation 
and decision-making. For placement of those elements that relied upon a high degree of judgment, the researchers looked for corroboration of a statement by one respondent by reference to the statements of other respondents.

\section{Master Foods Australia}

\section{Master Foods Background}

Master Foods was founded in 1926. It became part of the Mars family's group of companies in 1967. It is a family owned operation, engaged in diverse food production in 62 countries. Master Foods Australia is part of the Asia Pacific regional grouping within the Mars organisation. Master Foods operated in a number of Sydney locations until a green field site was established in Berkeley Vale, on the Central Coast of NSW in 1992. Master Foods Australia exports to Pacific Rim countries, as well as supplying the food service and industrial sectors.

\section{Results}

\section{The Infrastructure of Master Foods Australia}

The infrastructure consists of the hardware/software which enables the physical/communication contact between network members. In the instance of this analysis the definition has been extended beyond IT and communicational elements to include consideration of the physical work environments.

In common with Fuji Xerox Australia, Master Foods Australia has an extensive and ever-growing information management infrastructure. Whilst Master Foods is a good example of an organisation that operates very effectively in developing, retaining and utilising knowledge, until recently it hasn't pursued anything that it identifies itself as a knowledge management strategy. According to Hansen, Nohria and Tierney, Master Foods strategic choices consist of following either a codification (based on documents and storage, typically IT), or a personalization (individuals memories) approach (Hansen, Nohria and Tierney, 1999). Hansen et al prescribe an $80 / 20$ split, i.e. either $80 \%$ of effort, budget, being either codification or personalization, with the balance being of the complementary type. Hansen et al identify the extent to which organisational problems recur as being the criteria for which approach to adopt, with high rates of problems recurring being best dealt with through codification, and lower rates with personalization. Master Foods has adopted a strategy that is largely based on personalization. This choice reflects an organisational preference for high rates of verbal exchanges.

Master Foods does rely upon an intranet, with a portal established to capture all available knowledge. Master Foods has standardised survey tools made available to [for instance] identify needed training. Their Lotus Notes based databases are regional or local, rather than international. They rely upon Verity Knowledge Organiser to operate as something like an intranet browser, with it they have put 'Alex', an inhouse developed relational database, which captures visual and other files, and can search within documents for keywords. It has no vocabulary control, relying upon a consistency of vocabulary with users. 
A major change in 2003 has been a realisation in Master Foods of the need for better information management, and more consistency within the organisation as to how certain processes are performed. As explained by the IT Manager, this has been driven in particular by the power of customers. For example, customers sometimes have had a better understanding of Master Foods pricing than Master Foods itself has had. A global SAP system is being implemented to address these types of issues. Initially, 49 processes are being standardised within an MIS.

Communication within Master Foods is heavily oriented to verbal exchanges, reflected in fairly heavy reliance upon 'phone and videoconferencing. Master Foods is a 'lean' organisation. Even at very senior levels, secretarial support staff are rare. This issue is dealt with further under the examination of Master Foods' infoculture.

The Berkeley Vale office is unusual in that it features a huge, open-plan office, which facilitates communication across organisational boundaries. Here, about 200 people work in close proximity. Information sharing is almost inevitable, as the IT Manager explained; when a colleague approaches him with a problem, it is likely that he (the IT Manager) has already overheard much of the background to the problem. The Training Manager explained "Most people expect to be disturbed a couple of times a day for their opinion. .... As part of the orientation [process] we explain the terms of the open office are that you ask people questions" (Master Foods, Training Manager. 2001).

\section{Master Foods Infostructure}

The Infostructure is the formal rules which govern the exchange between the actors on the network, providing a set of cognitive resources (metaphors, common language) whereby people make sense of events on the network. In the instance of this analysis infostructure includes the formal reporting elements between Master Foods Australia and the worldwide Mars group.

On a day-to-day basis, Mars is guided by the five principles. These principles were created by 'associates' who work for Mars, (Mars eschews the term 'staff').

The principles are:

Quality: The consumer is our boss, quality is our work and value for money is our goal.

Responsibility: As individuals we demand total responsibility from ourselves; as associates we support the responsibility of others.

Mutuality: A mutual benefit is a shared benefit; a shared benefit will endure.

Efficiency: We use resources to the full, waste nothing and do only what we can do best.

Freedom: We need freedom to shape our future; we need profit to remain free.

Parallel with the recent structural changes in the Mars group, the Mars organisation has also sought to renew, and extend, the values encapsulated in these principles. The form in which this is being expressed is still in its infancy, but the essence of it is that it specifically recognizes the value of risk taking, work-force diversity and the need for staff to find satisfaction in their roles. In interview in 2003, the Strategic Communications Director stated: "I think it strengthens our case about being employer of choice...it's a very exciting vision, that is easy for Associates to articulate what's in it..." The express endorsement of some risk-taking has been welcomed by staff. The explicit endorsement of workforce diversity is also probably a 
reflection of an appreciation by senior Mars associates that the practice of recruiting to a cultural 'fit' or type, had resulted in something of an homogeneity that doesn't support organisational innovation.

Another notable feature of Master Foods is that its operations were for decades dominated by the Mars family, in particular the brothers, John and Forrest Mars. As the Mars family grew, the family made a very considered decision to move away from their very direct role in the running of the organisation to a more traditional approach. Today, long-time senior Mars managers are taking on the worldwide direction of the organisation, with the Mars family setting the broad direction of the organisation.

The example of John and Forrest Mars seems to endure. In interview, the R\&D Director stated: "They would give you a name of somebody you needed to talk to ... it was very much connecting you with people rather than projects." The IT Manager spoke of the role of key people within the organisation who remain as 'hubs' in the information wheel, the key networkers. In 2002, the IT Manager referred to one such person: “... he's the most wonderful source of what's actually happening in the organisation, he knows a phenomenal number of people out there, ... you tend to think 'he goes on every possible junket', but at the end of the day [he connects you with the right people]..." (Master Foods IT staff. 2002.) .

While Master Foods remains both diversified and informal in how it seeks and uses knowledge, it has also sought to formally reinforce pro-activity. The 'Making a Difference' awards, recognizing individual, outstanding performance, were instituted to encourage innovation, in particular. “....in the past risk-taking wasn't something that was considered a good attribute; ...People are now, even down at my level of the organisation, ... talking of having risk-taking as an active KRA [key responsibility area]...." (Master Foods IT staff. 2002.) . In 2003 The Strategic Communications Manager, in referring to the Making a Difference Awards, stated that she felt that the Award needed to reward not only successful, but also less successful initiatives. That, perhaps, would be the ultimate signal that the organisation accepts risk-taking. The Making a Difference Award now has an added criteria, which is the extent to which new knowledge was shared, or if a nominee had sought out knowledge from others in the organisation, and used it creatively.

\section{The Master Foods Infoculture}

The Infoculture is the stock of background knowledge which actors take for granted and which is embedded in the social relations surrounding work group processes. This cultural knowledge defines constraints on knowledge and information sharing. This includes examination of the exchanges between disciplines and national cultures and the preferences for the media for knowledge exchange.

Master Foods associates are pragmatic about how, or where, they find their knowledge. , “...we don't care where the knowledge comes from as long as it's good knowledge that we can use to move forward" (Master Foods Research \& Development Director. 2002). This suggests a highly pragmatic approach to knowledge acquisition, and an avoidance of the 'not invented here' syndrome that can preclude organisations successfully adopting 'outside' solutions.

Master Foods is highly reliant upon face-to-face or at least verbal communication. The Information Systems Analyst, when asked of the role of face-to-face contact, responded: "Invaluable. We use a lot of medium for communication, ..., utilising more than we probably even want to" (Master Foods IT staff. 2002.). Two 
interviewees spoke of the invasiveness of phone communication, in particular, with colleagues in SE Asia calling for support late into the evenings, and North American colleagues setting up teleconferences in the very early morning, Australian time. A recent global initiative was a 24 hour videoconference, starting with a new day in New Zealand, and rolling through to the end of a day in the US. Included in that videoconference was an address by the CEO of Mars.

Several staff we spoke with pointed to both the importance of face-to-face or at least verbal communication, coupled with a high reliance upon the reputation of the people they were dealing with. ".... and I think by and large most people would agree that we're not a reading organisation or a writing organisation... Trying to get someone to sit down and read document(s) is very difficult, whereas in ten minutes I [can have] them across the line in terms of a verbal presentation," (Master Foods Research \& Development Director. 2002).

Mars has initiated a global knowledge management initiative. It started in 2002 with a "Know to Grow" conference of senior Mars people in Lisbon. These were “...passionate Associates, not all IT, lead by IT \& R\&D. We agreed we needed someone to co-ordinate knowledge management initiatives." (Master Foods Communications Director. 2002). Attendees at the Lisbon conference donated budget, to enable employing someone in a nominated knowledge management position. The role of that person is currently being defined. "... the big thing to come out of it was that we don't want [just IT] systems. (Master Foods Communications Director 2002).

The cultural aversion to documentation remains a factor. The scarcity of secretarial support is a further impediment to the organisation documenting its knowledge. "What's been interesting in this one is that the Associates doing the projects haven't been terribly quick to load up their projects and data up on the Website, they've been more interested in getting on with it." (Master Foods Communications Director 2002).

This cultural preference for personalised rather than documented knowledge in Master Foods is surprising. The organisation seems to abound with strong ties between individuals that allow for free exchange of complex ideas. Yet, the knowledge management concerns of Master Foods predominantly relate to recurrent concerns, and their solutions would have universal application. For example, answers to the problem of effectively juicing a tomato in the US is probably applicable in Australia, ditto packaging product, or fixing common machine processes. Hansen (Hansen 1999), found that organisations marked by strong ties handle well the creation of complex knowledge to address non-recurrent problems, or innovation, but only within the bounds of the organisation. Organisations marked by strong internal ties can have difficulties accessing critical, outside knowledge. These organisations enable the building of strong ties via staff and client networking events, with a lesser emphasis on codification (production of manuals, or expert databases). Strong ties within an organisation militate against searching beyond organisational boundaries in the quest for solutions. It is remarkable that Master Foods has a culture that reinforces strong ties, and what expert databases exist tend to be regional, rather than global. Even where knowledge is documented, the source of the knowledge is subject to strong scrutiny by any potential users. The author's assessment is that the strong ties have arisen not so much to serve knowledge management, but for other purposes, primarily enabling effective organisational change.

In interview, both researchers were struck with the obvious strength of the Master Foods culture. When hiring graduates for example, they look for a specific type of person, not necessarily the top academic candidate but someone who can undertake a 
number of tasks at once, such as work and study. They specifically seek people who are team-oriented, proactive and unafraid to speak up, to contribute and to question propositions. The result is a decision-making process that can be quite protracted: "...We try to do as much as possible by consensus. Consensus normally results in a quality decision being made, but it usually means a very protracted, frustrating process...." (Master Foods IT staff 2002.) The dominance of this consensus approach may seem surprising, given that Master Foods is a US company, where the dominant style is autocratic. The preference for consensus decision-making may be a legacy of the style of the Mars family and Master Foods' long history of international operations.

Two respondents indicated that while Master Foods managed well in the processes of sense-making (understanding what is happening 'out there' in the market, for instance), and is capable in the creation of new knowledge. The third stage, - decision making, and in particular decision implementation, can be problematic. In interview with one IT person, she stated "... it's very hard to get a decision out of people you go to with a couple of alternatives". (Master Foods IT staff 2002). Beyond the decision making stage, implementation of those decisions can be less than orderly, with a variety of technologies and processes being used.

In common with Fuji Xerox Australia, respondents expressed the difficulty of successfully communicating with colleagues in SE Asia, in particular. "You're doing something with someone in Japan, and they're saying "yes, yes, yes", and what they're saying is "yes, we're hearing you", not "yes I agree with you, or have any intention of doing what you're asking me to do..." (Master Foods IT staff. 2002.)

There is a perception that Master Foods in some aspects it tends to follow, rather than lead the market; "...we are typically driven by the trade in E-commerce... we ran it when we were pushed, as opposed to the other way around." (Master Foods IT staff 2002). In other respects, Master Foods is proactive in understanding or shaping the external environment, making use of trade association links to advantage for such purposes as negotiating industry positions with governments.

\section{Fuji Xerox Australia}

\section{Fuji Xerox Australia Background}

Fuji Xerox Australia is the major regional operation of Fuji Xerox Asia Pacific (FXAP), based in Singapore. Fuji Xerox Australia is headquartered in North Ryde, Sydney. It is the product of a joint venture between a US company, Xerox, and the Japanese company, Fuji Photo Film. Fuji Xerox Asia Pacific (FXAP) includes Australia, NZ, Singapore, Malaysia, Thailand, Taiwan, Korea, Vietnam, and Indonesia. Hong Kong and China will shortly join the group. Xerox pioneered and progressed xerography, but has in recent years faced increased competition.

It is notable that two of our respondents have been with Fuji Xerox Australia, or the former Xerox Company, for a long time, 20 and 28 years. In interview with these people we were able to gain a sense of the long-run development of the organisation. 


\section{The Infrastructure of Fuji Xerox Australia}

The Australian operation is quite complex. This complexity (in particular its geographical dispersion) has resulted in many barriers. For example, in Sydney alone there is the Head Office and NSW Branch, along with two distribution centres, a technology centre and regional support centre, a re-manufacturing centre as well as the service force in various bases around the city. Exacerbating this geographic dispersion, the Head Office consists of numerous small offices, the antitheses of the office arrangement of Master Foods. Moving between functional areas commonly involves swiping cards or use of other security devices - disincentives for meeting face-to-face with colleagues in other functional areas. "You might see one person once a year, which means many people who are based in the office wouldn't know who other people are in the organisation." (Fuji Xerox Australia Finance Manager 2002).

Fuji Xerox Australia has a godfather system, for sharing knowledge horizontally in the organisation and encouraging senior managers to maintain their sensitivity to the "coal face" of the organisation. The Finance Director explained: “... I look after South Australia ... I share information about the top ten or twelve key indicators on how we're performing with customers ...This gives me an opportunity to gain feedback from the staff in that branch and gives them an opportunity to talk to someone at senior level." (Fuji Xerox Australia Finance Manager. 2002)

Fuji Xerox promotes itself as "The document company." It exchanges information locally, nationally and internationally using a plethora of IT systems. It promotes and uses knowledge management software, Docushare and Document Workbench, that it has developed. "... [Docushare] gives us the ability to put all of our procedures and processes up on the system and keep them up-to-date, and share information.... We are very much an electronic sharing company." (Fuji Xerox Australia Finance Manager. 2002) The infrastructure in Xerox has had a positive influence on the development of knowledge bases. The Human Resource, for example, might use the Canadian Web site to obtain information he required regarding a HR issue.

There is no current standard anywhere in Xerox for database organisation, which has lead to some problems where the plethora of available documents becomes a "Documaze" or "Docudump".

Other means for sharing information internationally include a database on global customers from the US from which information can be retrieved. For Fuji Xerox Australia it cannot be added to. The Finance Director elaborates on a more substantial database "The service force use ... Eureka which is a worldwide database which gives them the ability to understand the problems and accelerate the resolution of those problems. ... They're able to feed problems into a central database and our central support group look at that problem and come back with suggested solutions". (Fuji Xerox Australia Finance Manager 2002). Xerox is currently assessing this database as a way of making customers less reliant on a Xerox technician being available.

A summary of the IT applications Fuji Xerox Australia rely upon for knowledge management is as follows:

An Enterprise Resource Planning System (System 21 'GEAC')

A system that manages leasing and lease assets

A human resource management system

A management and reporting system

A field engineers call management and diagnostics system 
A program for call-center calls management, problem resolution and query management.

These systems are largely integrated. Even though these systems service Fuji Xerox Australia business well, System 21 may be replaced with a Fuji Xerox Asia Pacific wide Oracle system. The argument for implementing a centralized and integrated information systems across Fuji Xerox Asia Pacific are the potential benefits to be gained from better knowledge management throughout the supply chain, leading to savings through inventory management and also reduced lead times for products and inventory. One price for implementing such a large system may be a lessening of national suitability. Each country currently has a system which is customized to their specific requirements. The change being implemented will benefit many smaller players in the Asia Pacific group, but may be to the detriment of Fuji Xerox Australia.

Other technology such as video conferencing and telephone conferences are used for sharing knowledge. The Finance Director identified constraints of videoconferencing: “[it]...doesn't lend itself to workshops; it's more directional, oneto-one feedback ... if you're having a cross-cultural communication, it has to be on a face-to-face basis." (Fuji Xerox Australia Finance Manager. 2002)

\section{The Infostructure of Fuji Xerox Australia}

In terms of infostructure influencing international knowledge management capabilities, it may not be the complexity of the structure or the characteristics of the people in the structure, it may actually be where a company exists in the supply chain and the degree of their reliance on those further up the chain that impacts on their ability to gain information or influence the creation of knowledge and decision making. The National Product Manager illustrates: “...we are the tentacles at the end of the octopus, so to speak." (Fuji Xerox Australia National Product Manager. 2002)

As Fuji-Xerox Singapore continues to push for an Asia Pacific wide sharing of systems infrastructure the Australian "tentacle" has reservations. Their concerns revolve around the reduced suitability of the systems for local customers (and consequently reduced company profitability) in the global knowledge sharing structure. Given that Australia is the most profitable arm of FXAP, it will be interesting to see the outcome for the local profitability.

Fuji Xerox Australia's strategy has been to move away from being a provider of the 'box' that spits out copies, to a comprehensive provider of 'solutions' in document management, encompassing creation, storage, distribution, reproduction, disposal and archiving. This vision fits well with a prevailing business view of a holistic service that focuses more on business outcomes than products.

Within Fuji Xerox Australia the culture was characterised by interviewees as "tribal". The Finance Director illustrates: “[If] you're trying to communicate with service engineers, ... as it [the message] goes down to the second and third level it becomes diluted so people don't always know the reasons why or understand the rationale [behind a decision that has been made]" (Fuji Xerox Australia Finance Manager. 2002)

All interviewees identified regular face to face meetings as necessary parts of their communication across local, national or international boundaries. The concern is to reduce the 'silo' [tribal] and information dilution effect. The Commercial Manager 
referred to the enduring silo effect that sees valuable information generated by the direct sales force in the ELK customer contact manager program, being ignored or poorly utilised by the Fuji Xerox Australia business analysts. This highlights that infrastructure alone does not translate into successful sharing and maximising of knowledge within the organisation. Exchange of tacit knowledge is necessary for the continuing sharing and development of knowledge in the organisation

A problem that currently exists for Fuji Xerox Australia is what the National Product Manager describes as the "funnel of power and information" at the Singapore office. "[The Singapore] regional office supports the individual operating companies... we can't go to the manufacturer direct, that is the 'funnel of information'. Information coming out of Japan ... has to go through Fuji Xerox Asia Pacific. ... we go through our own launch process. Sometimes [the] information doesn't reach us in the time frame that we require."

The Finance Director also highlights that "We suffer in terms of [not] having the clear lines of communication from Japan, from an R\&D standpoint. We have a better feel for that from the US." (Fuji Xerox Australia Finance Manager. 2002)

The lack of people or contacts across a boundary also impedes communications. Having no direct contacts in Japan is a factor that may have exacerbated the funnel effect. The Finance Director laments that that “... While we try and influence, and we try and get as much information as we can on what's happening in the US [as they supply product to FXA] but progressively, over 10 or 11 years that's declined, because we've lost our contacts in the US." (Fuji Xerox Australia Finance Manager. 2002). This loss of contacts has occurred as Fuji Xerox has come to exercise its dominant part in the organisation and the US contacts previously at the heart of major decisions have come to play a lesser role.

The individual characteristics of people in the infostructure may be a barrier to the creation of knowledge or to decision making. For example, the Finance Manager emphasised that "We try to encourage decision-making right down to the lowest possible level ...- you empower people but they don't necessarily always use it." (Fuji Xerox Australia Finance Manager 2002).

For knowledge to continually be developed and shared in an organisation it is necessary for an infostructure to promote this by the use of existing infrastructure. By itself infrastructure will not result in the maximising of knowledge creation and dissemination.

It is noteworthy that there is not a translation service in Fuji Xerox. A document that may be developed in Australia that could be a useful source of knowledge is not shared purely due to a language barrier.

One enabling factor for sense-making, knowledge creation and decision-making is Fuji Xerox Australia's membership of the Office Equipment Industry Association. The Association generates a broad range of indicators from which members can derive a good view of their role relative to competitors in the industry.

\section{The Infoculture of Fuji Xerox Australia}

The culture of Fuji Xerox Australia has changed due to its change from being a predominantly Western organisation to a Japanese firm. The Finance Director stated: "I think the Japanese have taught us to be less reactive, more proactive.... [which is] fairly frustrating for someone whose style is, generally speaking, is an impulsive style..... We've had to stop and check and think longer term, which I think has been 
positive for us. It's been a good blend, and most of the senior managers, certainly at my level, have benefited from that. ... It'll take them 2 or 3 months to consider all these pieces of information." (Fuji Xerox Australia Finance Manager. 2002). The National Product Manager reinforced this, stating that the Japanese 'way' often "opened the eyes" of Australian managers. (Fuji Xerox Australia National Product Manager. 2002.)

As previously stated, Fuji Xerox Australia is "the document company". Employees are very technologically literate and they generally make good use of the comprehensive infrastructure that underpins the company. Decision making at the Australian level is generally done on a consensus basis. The flow of information is, however, compromised by the geographical dispersion of the Australian operations.

The Human Resources Manager referred to the instance of people in the same office using e-mail to resolve conflicts - stating "it doesn't work." (Fuji Xerox Australia Human Resource Operation Personnel Manager. 2002). The high division of labour within some parts of Fuji Xerox Australia can have the effect of people doing their job but not appreciating the importance of what they are doing. If, for instance, information is not entered in at the correct time in the Transport Planning Function of the Enterprise Resource Planning System [job planning], an engineer will not be made available to progress a job. A machine may remain idle for a number of days - to the frustration of the customer.

The Human Resources Manager expressed his views on the infoculture of Fuji Xerox Australia: “...the company vision is to move to a service organisation....The organisation has been around for ages, the current business dynamics is not going to change overnight." (Fuji Xerox Australia Human Resource Operation Personnel Manager. 2002).

In relation to the decision making, the Human Resources Manager had a particular view: "...it is my philosophy that you either have a lot of rules around decision making or you have a strong accountability. I think that we have a lot of rules but not a lot of accountability...People have a lot of authority to make decisions but there are a lot of rules which underpin [the process]."

The consensus-in-decision culture comes with a top-down management style. The Managing Director stated he doesn't like to give too much direction; he generally looks for a consensus approach. Where consensus is not forthcoming he is prepared to give the appropriate direction. (Fuji Xerox Australia Finance Manager. 2002)

The Fuji Xerox Australia Business Systems Manager characterised the culture of Fuji Xerox Australia as being 'tribal', despite numerous efforts to integrate disciplines.

The funnel between Singapore and Australia has inhibited knowledge creation and sharing significantly. Even with highly sophisticated infrastructure and infostructure, the infoculture needs to support knowledge creation and dissemination for potential gains to be realized.

\section{Analysis}

Both Fuji Xerox Australia and Master Foods can be seen as organisations in states of critical transition.

For Master Foods, the transition is from a quite unique, family led organisation to a more traditional multinational structure, with a large measure of local autonomy being encouraged. Master Foods remains a 'verbal' organisation, with many processes 
dependent upon relatively informal exchanges. Key individuals within the organisation encouraging and enabling knowledge exchange are perpetuating the former emphasis of Mars family led networking. This is not happening at the expense of IT development; rather it complements and enables that development. The major shift in 2003 is that the organisation has formally adopted a knowledge management strategy. This strategy appears to be having a careful implementation, with constituent parts being trialled and assessed before fuller implementation. The key Mars Associates recognise that a heavily IT-focussed initiative wouldn't succeed in the Mars environment. They will also look for some strong indications that their knowledge management investments are paying off in terms of financial performance.

Fuji Xerox Australia continues to show a very high state of information technology literacy. Fuji Xerox Australia succeeds through maximising return on the sale of premium, leading edge products and services. The organisation faces two critical transitions. The first is from being an essentially Anglo-American organisation, to a true multinational focus. Certain challenges remain for Fuji Xerox Australia in effectively working with its Japanese majority ownership. The second transition is from being a sales organisation, to being a 'solution' provider, with its implications of deeper relationships with clients and a cohesive, whole-of-organisation delivery of service.

Mars has successful knowledge management practices with a strong infoculture but relatively weak infrastructure. Fuji Xerox Australia appears to have an excellent foundation for knowledge management but to maximise this needs to strengthen their infoculture. Once Master Foods implements their new system, the result should be an improvement of the infrastructure. Will this have an effect on the infostructure and infoculture and what will be the consequences? Can Fuji Xerox Australia address the poor infoculture and will this translate into maximising knowledge management development and dissemination? Will this then impact on the bottom line?

\section{Directions for Future Research}

The research presented in this paper raises some practical concerns that could be addressed in future research:

The authors have inferred strong ties existing across all functional areas of Master Foods, and strong ties within the functional areas of Fuji Xerox Australia. Measuring the nature and strengths of those ties (using the method of Hansen (Hansen 1999)) could give further valuable insights to both organisations.

What is the appropriate balance of IT centred knowledge management vs. the peoplefocussed approach? Does this balance differ between the processes of sense-making, knowledge creation and decision making?

Does a reliance on infrastructure reduce the knowledge management by the effect it has on infostructure and infoculture.

Research means of measuring Infrastructure, Infostructure and Infoculture and identify if there are different levels suitable for different industries

\section{References}

Bressand, A. and Distler, C. 1995, La Planete Relationnelle. Flammarion, $<$ Paris $>$.

Choo, Chun Wei. 1997. The knowing organization: how organizations use information to construct meaning, create knowledge, and make decisions / Chun Wei Choo: New York: Oxford University Press, 1998. 
Fuji Xerox Australia Business System Manager. 2002. Interview. Hobson, Raelee, editor. North Ryde.

Fuji Xerox Australia Finance Manager. 2002. Interview. Meacheam, David \& Raelee Hobson, editors. North Ryde.

Fuji Xerox Australia Human Resource Operation Personnel Manager. 2002. Interview. Meacheam, David \& Raelee Hobson. North Ryde.

Fuji Xerox Australia National Product Manager. 2002. Interview. Meacheam, David \& Raelee Hobson. North Ryde.

Hansen, M. T., Nohria, N. and Tierney, T. 1999, "What's Your Strategy for Managing Knowledge?" Harvard Business Review, 77, pp. 106.

Hansen, M. T. 1999, "The Search-Transfer Problem: The Role of Weak Ties in Sharing Knowledge across Organization Subunits", Administrative Science Quarterly, 44, pp. $82(3)$.

Master Foods Communications Director. 2002. Interview. Meacheam, David \& Raelee Hobson. Berkeley Vale.

Master Foods IT staff. 2002. Interview Meacheam, David. Berkeley Vale.

Master Foods Research \& Development Director. 2002. Interview. Meacheam, David. Berkeley Vale.

Master Foods, Training Manager. 2001. Interview. Hobson, Raelee. Berkeley Vale.

Newell, S., Robertson, M., Scarbrough, H. and Swan, J. 2002, Managing Knowledge Work. Palgrave, Basingstoke.

Sarantakos, S. (Sotirios). 1993. Social research: South Melbourne : Macmillan Education Australia, 1993.

Spender, J. C. 1998, "Pluralist Epistemology and the Knowledge-Based Theory of the Firm", Organization, 5, pp. 233-56.

Yin, Robert K. (Robert Kuo-Zuir). 1994. Case study research: design and methods / Robert K. Yin. 2nd ed: Thousand Oaks, Calif.: Sage, c1994.

\section{About the Authors}

David Meacheam, Lecturer, School of eBusiness and Management, Central Coast Campus, Newcastle University

David lectures in human resource management, knowledge management and organisational learning at the Central Coast Campus of the University of Newcastle. He holds a BA (Library \& Information Science) from Charles Sturt University, and an MBA from the University of Newcastle. David's current research focus is upon the links between organisational type and knowledge management.

Raelee Hobson, Lecturer, School of eBusiness and Management, Central Coast Campus, Newcastle University

Raelee Hobson's experience includes time as a training officer for National Mutual in Sydney, where a training program she attended introduced her to mind mapping and creative learning. She has a B. Bus. (Management Information Systems) from the University of South Australia and M. Ed. (Computing) from Charles Sturt University). Raelee worked in education and business in Adelaide and Canberra before moving to the Central Coast. She currently consults with "Amazing People" a training organization that specializes in coaching, strategic planning and team building with organizations including Qantas, Johnson \& Johnson and Master Foods Australia. Raelee also lectures in Marketing and eBusiness at the Central Coast Campus at the University of Newcastle. Her research interest lies in creative learning in organizations, the methods of organizational learning in Australia and the effectiveness of these methods. 